DOI: $10.17951 / \mathrm{m} \cdot 2019.4 \cdot 23-37$

\begin{tabular}{lcr}
\hline & ANNALES & \\
& & \\
UNIVERSITATIS MARIAE CURIE-SKLODOWSKA & \\
LUBLIN - POLONIA & \\
VOL. IV & SECTIO M & 2019 \\
\hline
\end{tabular}

\title{
Ewa Godlewska
}

Maria Curie-Skłodowska University in Lublin ewa.godlewska@poczta.umcs.lublin.pl

ORCID ID: http://orcid.org/0000-0002-2550-7831

\section{Anti-immigrant rhetoric as an element of public life in Austria - selected aspects}

\section{Preliminary remarks}

In Austria, the number of people with immigrant roots has been increasing for several decades. This phenomenon is primarily the result of the recruitment system implemented since the 1960s (Gastarbeitersystem) and the subsequent family reunification process. At that time, many inhabitants of former Yugoslavia came to Austria (including Bosnia and Herzegovina, Serbia and Montenegro), as did Turks. During the Cold War, Austria also became a shelter for political refugees from Hungary, the Czech Republic and Poland. Recent years, however, have shown an increase in the influx of people from Chechnya, Afghanistan, Iraq, Somalia, and then from Syria. The number of new applications for asylum increases every year. In 2015, the number of immigrants was the highest in recent decades. At that time, Austria had the fourth-largest number of asylum applications in the EU, preceded by Germany, Hungary and Sweden ${ }^{1}$.

A year later the influx of people was slightly slowed down. In terms of the number of asylum applications, Austria was fifth in the EU after Germany, Italy,

\footnotetext{
1 Migration und Integration. Zahlen, Daten, Indikatoren, 2016, p. 9.
} 
France and Greece. However, per capita, only Germany accepted more immigrants than Austria ${ }^{2}$.

Changes in the ethnic makeup of Austrian society, including the number of inhabitants of the host country, have become more apparent. What is more - out of almost 2 million people with immigrant roots residing In Austria in 2016, the majority (1.4 million) were immigrants from the first generation ${ }^{3}$.

Nowadays, Austria is facing significant challenges in establishing integrational policy towards immigrants. Its basic assumption is to enable economic inclusion as soon as possible. On the other hand, integration programs generate quite high costs, and this fact is repeatedly pointed out in public discussion. The emerging social scepticism towards immigration has become one of the reasons for the electoral success of the far right, which is considered to be the anti-immigrant Freedom Party of Austria (Freiheitliche Partei Österreichs/ FPÖ).

Due to the limited framework, the text focuses on only one dimension of public life - the Austrian political scene. The article undertakes an analysis of a selected topic, including several aspects: the attitude of political parties ${ }^{4}$ towards so-called immigration issues an, the nature of election campaigns and government initiatives on Austria's immigration policy. On the other hand, the questions raised in the paper concern the following issues: when dis the change in the nature of public discussion in Austria come about, under what influence have the factors of antiimmigrant rhetoric intensified and what are the effects of such rhetoric? Another important issue is whether only the Freedom Party of Austria remains the carrier of such rhetoric.

The author used primarily the decision-making metho, in which phenomena and processes are considered through the prism of the decision-making center, the decision-making process, as well as the political decision. Specifying the similarities and differences between the processes and phenomena studied allowed, in turn, to apply the comparative method.

Political parties towards the immigrant issue

Among the parties whose contemporary position on the Austrian political scene remains the strongest, the formation showing the greatest dislike towards immigrants is the Freedom Party of Austria. Its slogans derivs from a specifically un-

${ }^{2}$ Migration und Integration. Zahlen. Daten. Indikatoren 2017, pp. 8 - 9.

3 Ibidem, p. 9.

4 The article only analyzed the three strongest groups that most often form governments in Austria - the Austrian People's Party, the Social Democratic Party of Austria and the Freedom Party of Austria. 
derstood concept of ethnicity that originates from the concept of Heimat. Heimat literally means homeland. However, according to the Austrian Freedom Party, it should be understood as a "native cultural identity" rather than a geographical homeland, as In the past, a nation was defined as a linguistic and cultural community based on origin and history. In addition, party activists were in favor of most Austrians belonging to the German ethnic and cultural community, which was a clear reference to the idea of pangermanism ${ }^{5}$. Such formulations were included in the 1985 FPÖ program 6 .

The above document also contained references to the issue of labour migration. The creators of the charter documenm did not deny immigrants rights to decent working conditions and remuneration. However, they were against any political rights. They also drew attention to the social aspects of their presence on Austrian territory. Economic immigration should, in the authors' opinion, be considered in terms of the threat to native workers. The priority wa therefore to strive for full employment of Austrian citizens and to gradually reduce the number of foreigners. The claim that Austria is an immigrant country was therefore to be negated.

In the following years, the attitude towards immigrants did not change. Further party programs emphasized that Austria, due to its location, social structure, population density and resources, is not and should not be an immigration country. Strong opposition was expressed against an unrestricted and uncontrolled influx of people, arguing that this would be necessary to protect their own citizens. Thus, a restrictive (and according to party leaders - responsible) asylum policy was advocated. Herein, Protection should only be granted to those who are genuinely persecuted, and the authorities' efforts should focus on supporting the return of foreigners to their countries of origin.

In 2005, Heinz-Christian Strache became chairman of the party. The FPÖ was even more radicalized under his rule. Anti-immigrant and anti-Islamic slogans have also gained strength.

In the latest FPÖ program of June $18,2011,{ }^{7}$ even more emphasis was placed on protecting the interests of Austrian society. Defending the homeland as part of the

5 The Freedom Party of Austria was officially cut off from this idea only in 1997. Instead, the party's charter documents utilize the term 'Austrian nation. Das Parteiprogramm der Freiheitlichen Partei Österreichs 1997, mit Berücksichtigung der beschlossenen Änderungen vom 27. Ordentlichen Bundesparteitag der FPÖ am 23. April 2005 in Salzburg.

6 Das Programm der Freiheitlichen Partei Österrreichs, Beschlossen am Parteitag 1. 凶2. Juni 1985 in Salzburg.

7 Parteiprogramm der Freiheitlichen Partei Österreichs (FPÖ). Beschlossen vom Bundesparteitag der Freiheitlichen Partei Österreichs am 18. Juni 2011 in Graz, https://www.fpoe. at/fileadmin/user_upload/www.fpoe.at/dokumente/2015/2011_graz_parteiprogramm_web.pdf [access: 18.07.2019]. 
German-language cultural community has become a priority. Austria is to protect its territory and the interests of its citizens, but also to remain neutral at all costs. The duties of the state administration include care for tradition, identity and culture.

Criticism of Austria's immigration policy has become one of the strongest accented program slogans. The presence of immigrants, according to activists, has become a burden for the state, and assistance addressed to them was provided, inter alia, at the expense of retirement benefits. Therefore, stopping immigration becomes a prerequisite for protecting cultural identity and "social security" in Austria. Referring to earlier program assumptions, it was once again emphasized that Austria cannot be treated as an immigrant state. The party leaders argued, however, that their reluctance was not directed at foreigners, but against "system burdens".

Given the differences between economic immigrants (whose inflow should be significantly reduced) and refugees, party leaders spoke to help the latter. However, such assistance should depend on the attitude of the persons granted protection. Recipients of assistance can only be foreigners legally residing in the state, respecting Austrian law and integrating with society. Mandatory German courses are a basic element of integration. Lack of progress in the integration process should mean the loss of all state benefits. Such benefits should also be temporary and may be used only by refugees. Economic immigrants have no rights to them.

In addition, state action should be directed at combating abuse on the part of asylum seekers in Austria, and priority must be given to the interests of their own citizens. This right should be strictly removed from persons who have committed crimes.

An element of "integration obligation" appeared in the party's program assumptions. According to FPÖ leaders, submission to such a process should be seen as a kind of repayment of debt by immigrants in relation to the host country.

The party's main slogan was "Austria first" ("Österreich zuerst"). Caring for their own citizens is for FPÖ, a reference point for other activities and an element of patriotism understood in a specific way.

The party's program highlights the fact that other areas of public life are viewed through the lens of immigration policy. This phenomenon can be seen on at least three levels. Security issues are of particular importance in this respect. Leaders are calling for a reduction in expenses for immigrants and refugees and an increase in expenditure on law enforcement and combating cross-border crime. Furthermore, in their eyes, Every foreigner who had committeg a crime should be expelled from Austria. Immigration policy has also been correlated with social policy. Social benefits should, according to party members, be linked to citizenship. Thus, the right to family benefits, social housing and many other forms of assistance should not be granted to immigrants. Thirdly, education policy should be mentioned. From 
the point of view of the topic taken up, the FPÖ's Postulate became the primacy of German in education, hence. German should be the only language of instruction.

In recent years, activists of the Austrian People's Party (Österreichische Volkspartei/ ÖVP) have also increasingly focused their attention on immigration policy. The latest party program dates from $2015^{8}$. People in it opted for a modern state in which both majority and minority rights are respected. Here, Respect for cultural diversity should go hand in hand with concern for one'r own cultural identity. A sign of this concern was to be, among others, a policy towards foreigners based on integration activities in society. According to party activists, the influx of foreigners cannot be allowed "at the expense" of the local population. Austria may be a country friendly to immigrants, but policy towards them should take into account the possibilities of the labor market, housing or even education.

The politicians of the Austrian People's Party have also supported the socalled integration package (Integrationspaket), including activities to raise the level of German language proficiency. Participation in special language courses with a positive result was to be a condition for obtaining permission to extending $r$ stay in Austria.

In the Program Document of the Social Democratic Party of Austria (Sozialdemokratische Partei Österreichs / SPÖ) from 1998, ${ }^{9}$ tolerance towards national minorities remained an important slogan. The program includes general provisions on equal rights for minorities, the right to full integration, identity maintenance, as well as that of own language and culture. The need to promote upbringing in a spirit of tolerance and dialogue, mutual respect for people of different ethnicity, cultural, linguistic or religious identity was emphasized. The latest party program was adopted in $2018^{10}$. In many points it coincides with previous postulates. However, the document puts even more emphasis on the increasing diversity of Austrian society, indicating that already about $1 / 5$ of the population has immigrant roots. In this context, comprehensive integration activities are the responsibility of the authorities. At the same time, the authors of the program, noting the nature of the public debate in Austria, explicitly opposed the politicization of the "ethnic issue".

8 Grundsatzprogramm der Österreichischen Volkspartei, 2015, https://www.wien.oevp.at/ wp-content/uploads/2017/06/grundsatzprogramm_oevp_2015.pdf [access: 16.01.2019].

9 SPÖ, Das Grundsatzprogramm, https://spoe.at/das-spoe-parteiprogramm [access: 16.01.2019]. The document replaced the party program of 1978.

${ }^{10}$ SPÖ, Das Grundsatzprogramm Die Welt steht nicht still, Beschlossen am 44. ordentlichen Bundesparteitag in Wels 2018, https:/www.spoe.at/wp-content/uploads/sites/739/2018/12/ Parteiprogramm2018.pdf [access: 28.05.2019]. 


\section{Anti-immigrant rhetoric in electoral campaigns}

Over the past few years, there has been an increase in interest in the so-called immigration issue. Election campaigns have become one of the manifestations. Increasingly, individual political groups have reached for slogans about the migration crisis in Europe. This process was most visible in the case of the FPÖ, which after 2010 began to record political successes again ${ }^{11}$.

In October 2015, in the local elections in Vienna, the FPÖ achieved a record result of $32.2 \%$ of the vote. During the election campaign, the party leader- HeinzChristian Strache- demanded the strengthening of border controls, preferential treatment for Christian immigrants and defending the "western nature of Austria". He further claimed that in order to stop the influx of foreigners on the Austrian border, a fence should be erected ${ }^{12}$. the FPÖ candidate in the 2016 presidential election Norbert Hofer, based his campaign on similar slogans. In the end, he lost the election with a slight difference of votes to an independent candidate - Alexander Van der Bellen, but the result of the election was a signal of a change in public mood.

Early parliamentary elections were held in Austria on October 15, 2017. The FPÖ, with $26 \%$ support, took third place, but the transition of the Social Democrats to the opposition opened the way for coalition talks between the victorious ÖVP and the Austrian Freedom Party. As a result of the talks, a coalition government was formed under the leadership of Sebastian Kurz.

One of the leading topics of the 2017 election campaign was immigration policy. The person who largely contributed to this again was the FPÖ leader HeinzChristian Strache. The speech given by the FPÖ leader in October 2017 aroused significant public interest. In it, H.-Ch. Strache described Angela Merkel as the most powerful, but also the most dangerous woman in Europe. At the same time, he accused the German Chancellor of the exacerbation of the migration crisis on the continent, and called the immigration policy that she supported and forced, criminal. He also stated that he would dend assistance to immigrants who abuse

${ }^{11}$ One of the first successes at the federal level was the candidate for the party - Barbara Rosenkranz - second in the presidential election in 2010. The politician became famous for her very radical views. She questioned the existence of gas chambers during World War II and believed that the ban on glorifying the Nazis was not in line with the constitutional principle of freedom of speech. She also denied the Holocaust.

${ }^{12}$ Lewica wygrywa wybory, 2015, http://wpolityce.pl/swiat/268119-lewica-wygrywa-wybory-w-austrii [access: 21.04.2016]. 
the right to protection and hospitality of host countries, as well as disregardeg democratic principles ${ }^{13}$.

During the mentioned election campaign, H.-Ch. Strache demanded a change in Austria's immigration policy. He was in favor of more stringent solutions. Furthermore, He expressed positively the actions taken by the current Hungarian and Polish governments.

The FPÖ election program highlighted the growing dislike of Islam. Party leaders emphasized the need to engage in the protection of religious freedom while combating all forms of religious fanaticism. They opposed the wearing of face-covering scarves in public space, and They were against the influx of immigrants from Muslim countries. In relation to Islam's followers who live in Austria, they called for strict control of mosques, schools and religious kindergartens. The program and activities initiated by FPÖ activists showed a correlation between Islam and the threat of religious fanaticism. Once again, support was given to stopping immigration, thus criticizing the "open door" policy. First of all, economic immigration was negated. The state should only help persecuted people who are seeking asylum in Austria. However, such assistance must be temporary. Anyone who misuses their right to asylum should be deported immediately. It was also proposed that cash benefits be replaced by in-kind assistance. In addition, Humanitarian problems, which are one of the reasons for the influx of foreigners, should be solved at the place of conflict. The EU's policy on border control and free movement of persons has also been criticized $^{14}$.

Interestingly, the above rhetoric was largely adopted by the ÖVP leader - S. Kurz. The future chancellor also argued for more stringent border controls, limiting Islam's role in public life, and reducing benefits for foreigners. According to him, social benefits were one of the factors attracting immigrants. Sebastian Kurz, at the time, still in the role of Minister of Foreign Affairs in the Christian Kern government, was often asked to discuss the subject of excessive costs incurred by Austria in connection with immigration policy.

As a result of the collapse of the ruling coalition, on September 29, 2019, early parliamentary elections were held in Austria. Again, immigration policy became one of the main topics. These issues were strongly stressed in the election program of

${ }^{13}$ FPÖ-Chef nennt Merkel „gefährlichste Frau Europas", 2017, https://www.welt.de/politik/ ausland/article159005873/FPOE-Chef-nennt-Merkel-gefaehrlichste-Frau-Europas.html [access: 12.01.2018].

${ }^{14}$ Freiheitliches Wahlprogramm zur Nationalratswahl 2017, https://www.fpoe.at/fileadmin/user_upload/Wahlprogramm_8_9_low.pdf [access: 21.09.2018]. 
the Freedom Party of Austria which has already been mentioned many times) ${ }^{15}$. Its leaders opposed multicultural policiey, thus supporting the unity of society. Furthermore, they held that Asylum policy should be pursued consistently, and any abuse in this area should be severely punished. In addition, Asylum seekers in Austria should cover the costs of the procedure. All offenses against applicable law, as well as trips to country of origin should automatically mean the loss of protection. At the same time, the temporary nature of asylum protection was underlined. After the reasons for granting it cease to exist, persons should leave the country's borders. Herein, Climate change and poverty cannot be considered as a legitimate reason for asylum. On the issue of electoral rights, party members clearly expressed their support for granting them only to Austrian citizens. The party's electoral program once again devoted a lot of attention to Islam. Lack of tolerance for radicalism, the primacy of national law over religious law, the prohibition of wearing in public places oc costumes covering the body and face were some of the slogans of the campaign.

In 2019, two issues remained at the heart of the election program of the Austrian People's Party: reducing the tax burden and combating illegal immigration. Regarding the second area, the ÖVP leader - S. Kurz - announced the continuation of a course aimed at further tightening asylum and integration policy. He objected to abuses in helping immigrants and their families, and He proposed creating a special group to control the benefits paid to them. The party's election program once again stressed the need to comply with the legal system and democratic principles in force in Austria. As part of the counter tt religious extremism, the part announced the dissolution of extreme associations, greater control over the teaching system and the continuation of the fight against hatred online ${ }^{16}$. What draws attention is the fact that the slogans proclaimed were primarily anti-Islamic. In Austria, this religion is identified primarily with immigrants.

In the SPÖ election program, however, the key was 'integration before immigration'. According to social democrats, responsible immigration policy is to follow clear rules for providing protection, equal opportunities, strengthening of the integration offer, solidarity of European countries and efforts to help countries of immigrant origin. While Criticizing illegal immigration, party leaders were at the same time against intimidation of society and building negative stereotypes ${ }^{17}$.

\footnotetext{
${ }^{15}$ Mit Sicherheit für Österreich: Fair, Sozial, Heimattreu, Wahlprogramm NRW 2019, https://www.fpoe.at/wahlprogramm-nrw-2019/mit-sicherheit-fuer-oesterreich-fair-sozial-heimattreu/ [access: 20.09.2019].

${ }^{16}$ Nationalratswahl 2019: Das Wahlprogramm der ÖVP, https://www.vienna.at/nationalratswahl-2019-das-wahlprogramm-der-oevp/6334803 [access: 21.09.2019].

17 „Menschlichkeit siegt." - Mit unserem Wahlprogramm!, https://www.spoe.at/wp-content/ uploads/sites/739/2019/09/Wahlprogramm-im-\%C3\%9Cberblick.pdf [access: 21.09.2019].
} 


\section{The Austrian government towards immigrants}

The phenomenon of intensified migration movements in Europe in the second decade of the 21 st century in Austria has caused several significant changes on the political scene. The most important were the resignation of two chancellors from the SPÖ - Werner Faymann and Christian Kern ${ }^{18}$, as well as the creation of a new government under the leadership of S. Kurz, which, in addition to the Austrian People's Party, also included the Freedom Party of Austria.

The presence of the FPÖ in the government established in 2017 could have meant restrictive changes in immigration policy. The government's program assumption and first initiatives confirmed these assumptions. However, it should be emphasized that some changes in this area could already be observed at the turn of 2015 and 2016. This was associated with announcements of limiting the inflow of immigrants to Austria. The then Chancellor W. Faymann was in favor of strengthening border controls and speeding up the deportation procedure for persons who do not meet the conditions necessary to receive asylum. He als did not rule out the use of force. Moreover, He increasingly criticized Angela Merkel and described her actions as a "magnet" for immigrants ${ }^{19}$. The following months brought further announcements of a tightening of Austria's immigration policy. Stilr, it was only the first decisions of S. Kurz's government that providee a clear statement as to how to resolve the "immigrant issue". These decisions resulted from the program assumptions of the new cabinet for 2017-2022 "Together - For our Austria" ("Zusammen. Für unser Österreich" $)^{20}$. The protection of the homeland and its culture has become a priority under this government. As a consequence, it was meant to include the right to decide on the shape of immigration policy and stop the illegal influx of foreigners. At the same time, the government called for more effective protection of the EU's external borders. He also criticized the pressure exerted on European countries in connection with the migration crisis.

The program assumptions devote a lot of attention to integration. The importance of obligations on the part of immigrants was emphasized. It is also significant that the issues devoted to integration processes are included in the chapter on order and security (Ordnung und Sicherheit). The authors of the program have declared

\footnotetext{
${ }^{18}$ W. Faymann, after less than eight years, stepped down as head of government on May 9 , 2016, his successor - December 18, 2017.

${ }^{19}$ Ende einer Polit-Romanze, http://www.sueddeutsche.de/politik/fluechtlingspolitik-faymann-und-merkel-ende-einer-polit-romanze-1.2923727, [access: 28.03.2016].

${ }^{20}$ Regierungsprogramm 2017 - 2022, Zusammen. Für unser Österreich, 2017, https:// www.bundeskanzleramt.gv.at/documents/131008/569203/Regierungsprogramm_2017 \%e2\%80\%932022.pdf/b2fe3f65-5a04-47b6-913d-2fe512ff4ce6 [access: 23.04.2018].
} 
a reduction in social benefits for newly arrived immigrants and asylum seekers. However, the program also granteg so-called integration bonuses for active participation in integration courses and in finding a job. On the other hand, the refusal to participate in the courses meant higher financial sanctions.

Detailed assumptions of the new government can be reduced to a few slogans:

- amendment of asylum law towards tightening and accelerating procedures;

- increasing the scope of "integration obligations";

- expanding the list of safe countries of origin;

- consistent and effective deportation of persons whose applications have been rejected;

- the option of taking up cash to cover basic care costs;

- more effective verification of personal data;

- greater oversight of immigrants;

- increasing the powers of law enforcement;

- prohibition of work for persons residing without authorization in Austria;

- more effective border control;

- revision of the rules on granting citizenship.

The key for internal policy was the announcement by the government on April 18, 2018 of draft amendments covering, among others, the Act on foreigners. It included points such as the right to inspect mobile phons, for faster verification of the identity of foreigners and their travel routes, greater supervision over the housing of asylum seekers, for faster deportation in the event of rejection of an application, and the possibility of seizing funds to cover the costs of primary care (up to 840 euros). Refugees committing criminal acts were to be immediately placed in deportation detention and consistently expelled from Austria. Underage criminals were also to be subjected to this procedure. Trips to their homeland were to mean automatic loss of protection ${ }^{21}$.

On July 1, 2018, Austria began its presidency of the Council of the European Union, taking it over from Bulgaria. The motto "Europe that protects" then become its leitmotiv. In the government program on the presidency of the Council of the European Union (Program of the Austrian Presidency. Presidency of the Council of the European Union 1 July-31 December 2018) migration issues wome one of the main priorities. Accordingly tThe Austrian Chancellor described the situation of the second decade of the 21st century as "the largest migration crisis in Europe since World War II". The Austrian proposals primarily focused on strengthening

${ }^{21}$ Bundeskanzler Kurz: Mehr Sicherheit und Deutschklassen beschlossen, 2018, https:// www.bundeskanzleramt.gv.at/-/bundeskanzler-kurz-sicherheit-und-deutschklassen [access: 25.05.2018]. 
the European Border and Coast Guard Agency, which was to guarantee effective protection of the EU's external borders. Attention was also paid to the need to improve the solutions in force in the Schengen area, including the improvement of the functioning of the Schengen Information System (SIS) and the possibility of establishing longer periods for the introduction of border controls in cases of a serious threat to internal security ${ }^{22}$. In the presidency program assumptions, Austria also drew attention to the need for rapid implementation of two regulations: the regulation on the EU travel information system and travel permits ETIAS (European Travel Information and Authorization System) ${ }^{23}$, as well as the regulation on the EES (The Entry-Exit System) ${ }^{24}$. The first system is to collect data frerstravellers from third countries whose citizens have been exempted from the visa requirement. The second is to generate data on the entry and exit of third-country nationals into the EU. According to the assumptions, the ETIAS and EES systems are to support the fight against crime and terrorism, illegal immigration and to serve as a tool to improve border management.

S. Kurz also announced an increase in efforts to develop common principles for asylum policy. He expressed support for more flexible, but at the same time rigorous solutions, which were supposed to reduce pressure on Member States. The Austrian authorities were, therefore, critical of the effectiveness of the obligation to implement the quota system. The use of return incentives, a faster expulsion procedure in the event of violations of the right of asylum, the creation of reception centers outside the territory of EU Member States and more effective enforcement of respect for "European values" are some of the ideas that were intended to offset the effects of the migration crisis in Europe.

Safety has become Austria's priority. In principle, all presidency program points were subordinated to this issue. Note that the key concept was used primarily to refer to phenomena known as the migration crisis in Europe. The presidency's slogan "Europe that protects" has become eloquent in this context. The program high-

22 J. Szymańska, Kontrole na granicach wewnętrznych strefy Schengen: wyjątki stają się reguta, Biuletyn PISM Nr 17 (1590), 2018

${ }^{23}$ Proposal for a Regulation of the European Parliament and of the Council establishing a European Travel Information and Authorisation System (ETIAS) and amending Regulations (EU) No 515/2014, (EU) 2016/399, (EU) 2016/794 and (EU) 2016/1624, Brussels, 16.11.2016, COM (2016) 731 final

${ }^{24}$ Proposal for a Regulation of the European Parliament and of the Council establishing an Entry/Exit System (EES) to register entry and exit data and refusal of entry data of third country nationals crossing the external borders of the Member States of the European Union and determining the conditions for access to the EES for law enforcement purposes and amending Regulation (EC) No 767/2008 and Regulation (EU) No 1077/2011, Brussels, 6.4.2016 COM(2016) 194 final 2016/0106 (COD). 
lighted the dangers of illegal immigration. Therefore, one of the more frequently cited passwords was, among others, the need to protect external borders, the fight against radicalization, terrorism and organized crime, or even the promotion and protection of "European values".

\section{Final remarks}

In recent years, increased anti-immigration rhetoric can be observed in Austria. This is not a new phenomenon. We ad similar phenomena back in the 1990s. At the turn of January and February 1993, at the initiative of the FPÖ, a referendum was organized tich was to become a stimulus to introduce a restrictive immigration policy, including the tightening of border controls. The referendum was held under the slogan "Austria first". The initiators of the referendum did not, however, achieve political success. Only 417 thousand Austrian citizens participated in it ${ }^{25}$. However, this event was a signal that the FPÖ could and above all would be able to mobilize voters in the future based on anti-immigrant rhetoric. This happened a dozen or so years later.

In the second decade of the 21st century, anti-immigration slogans in Austria gain new meaning. They become an element of public life. The main carrier of this rhetoric today is the Freedom Party of Austria. Some of the proposals were also taken over by the Austrian People's Party (ÖVP). However, ÖVP's program assumptions were more balanced and contained concrete proposals for resolving the migration issue, wheras. Frs usually resorred to fear mongering and other negative emotions. In contrast iImmigration policy was not the main topic of SPÖ's election campaigns. The party's program was rather primarily focused on social issues, such as the pension system, health care, combating poverty, but also climate change. However, none of the leading parties denied the mandatory nature of integration. Accordingly aAssistance should be subject to compliance with certain requirements.

Actions taken by the last government of S. Kurz clearly show a willingness to limit the inflow of foreigners to the territory of Austria. However, it is difficult to call them a new strategy. Rather, it is about continuing previous ventures. The program assumptions have some new features (e.g. the possibility of takier over cash to cover the costs of basic care), but in general many issues have been raised and implemented before. Sebastian Kurz, however, acted consistently. Limiting the influx of foreigners, increasing border controls, reducing benefits for foreigners, as well as greater control over Islam are some of the assumptions of his government.

${ }^{25}$ R. Gärtner, The FPÖ, Foreigners, and Racism in the Haider Era, in: The Haider Phenomenon in Austria, Wodak R., Pelinka A. (eds.), New Brunswick, New Jersey 2002, pp. 23 - 24. 
As a result of early parliamentary elections that took place on September 29, 2019, the Austrian People's Party won again (with 37.5\% support). The Social Democratic Party of Austria came in second (21.2\%). The FPÖ had a worse result than previous elections. eyHe gained $16.2 \%$ of the vote, which was a worse result by almost $10 \%$ compared to the 2017 election. In contras, tThe Green Party (die Grünen/die Grüne Alternative) obtained a good result (13.9\%) ${ }^{26}$. It should be noted that trhis political program is most friendly to national minorities and immigrants. However, it is difficult to expect that this grouping will be part of the new government. This has not happened in the party's history so far.

The mission to form a new government was again entrusted to Sebastian Kurz. This allows us to draw conclusions that the political line adopted by his previous government will continue. This will happen especially when the FPÖ becomes a coalition partner again (which Kurz did not rule out before the election).

\section{Bibliography}

- Bundeskanzler Kurz: Mehr Sicherheit und Deutschklassen beschlossen, 2018, https:// www.bundeskanzleramt.gv.at/-/bundeskanzler-kurz-sicherheit-und-deutschklassen [access: 25.05.2018].

- Das Parteiprogramm der Freiheitlichen Partei Österreichs 1997, mit Berücksichtigung der beschlossenen Änderungen vom 27. Ordentlichen Bundesparteitag der FPÖ am 23. April 2005 in Salzburg.

- Das Programm der Freiheitlichen Partei Österrreichs, Beschlossen am Parteitag 1. 2. Juni 1985 in Salzburg.

- Ende einer Polit-Romanze, http://www.sueddeutsche.de/politik/fluechtlingspolitikfaymann-und-merkel-ende-einer-polit-romanze-1.2923727, [access: 28.03.2016].

- FPÖ-Chef nennt Merkel "gefährlichste Frau Europas", 2017, https://www.welt.de/ politik/ausland/article159005873/FPOE-Chef-nennt-Merkel-gefaehrlichste-FrauEuropas.html [access: 12.01.2018].

- Freiheitliches Wahlprogramm zur Nationalratswahl 2017, https://www.fpoe.at/fileadmin/user_upload/Wahlprogramm_8_9_low.pdf [access:21.09.2018].

- Gärtner R., The FPÖ, Foreigners, and Racism in the Haider Era, in: The Haider Phenomenon in Austria, Wodak R., Pelinka A. (eds.), New Brunswick, New Jersey 2002.

- Grundsatzprogramm der Österreichischen Volkspartei, 2015, https://www.wien. oevp.at/wp-content/uploads/2017/06/grundsatzprogramm_oevp_2015.pdf [access:16.01.2019].

- Lewica wygrywa wybory, 2015, http://wpolityce.pl/swiat/268119-lewica-wygrywawybory-w-austrii [access: 21.04.2016].

- Migration und Integration. Zahlen, Daten, Indikatoren, 2016.

- Migration und Integration. Zahlen. Daten. Indikatoren, 2017.

${ }_{26}$ Nationalratswahl 2019, Bundesministerium für Inneres, https://bmi.gv.at/412/Nationalratswahlen/Nationalratswahl_2019/ [access: 10.10.2019]. 
- Mit Sicherheit für Österreich: Fair, Sozial, Heimattreu, Wahlprogramm NRW 2019, https://www.fpoe.at/wahlprogramm-nrw-2019/mit-sicherheit-fuer-oesterreich-fairsozial-heimattreu/ [access: 20.09.2019].

- Nationalratswahl 2019, Bundesministerium für Inneres, https://bmi.gv.at/412/Nationalratswahlen/Nationalratswahl_2019/ [access: 10.10.2019].

- Nationalratswahl 2019: Das Wahlprogramm der ÖVP, https:/www.vienna.at/nationalratswahl-2019-das-wahlprogramm-der-oevp/6334803 [access: 21.09.2019].

- Parteiprogramm der Freiheitlichen Partei Österreichs (FPÖ). Beschlossen vom Bundesparteitag der Freiheitlichen Partei Österreichs am 18. Juni 2011 in Graz, https://www. fpoe.at/fileadmin/user_upload/www.fpoe.at/dokumente/2015/2011_graz_parteiprogramm_web.pdf [access: 18.07.2019].

- Proposal for a Regulation of the European Parliament and of the Council establishing a European Travel Information and Authorisation System (ETIAS) and amending Regulations (EU) No 515/2014, (EU) 2016/399, (EU) 2016/794 and (EU) 2016/1624, Brussels, 16.11.2016, COM (2016) 731 final

- Proposal for a Regulation of the European Parliament and of the Council establishing an Entry/Exit System (EES) to register entry and exit data and refusal of entry data of third country nationals crossing the external borders of the Member States of the European Union and determining the conditions for access to the EES for law enforcement purposes and amending Regulation (EC) No 767/2008 and Regulation (EU) No 1077/2011, Brussels, 6.4.2016 COM(2016) 194 final 2016/0106 (COD)

- Regierungsprogramm 2017 - 2022, Zusammen. Für unser Österreich, 2017, https:// www.bundeskanzleramt.gv.at/documents/131008/569203/Regierungsprogramm_2017 \%e2\%80\%932022.pdf/b2fe3f65-5a04-47b6-913d-2fe512ff4ce6 [access: 23.04.2018].

- SPÖ, Das Grundsatzprogramm Die Welt steht nicht still, Beschlossen am 44. ordentlichen Bundesparteitag in Wels 2018, https://www.spoe.at/wp-content/uploads/ sites/739/2018/12/Parteiprogramm2018.pdf [access: 28.05.2019].

- SPÖ, Das Grundsatzprogramm, https://spoe.at/das-spoe-parteiprogramm [access:16.01.2019].

- Szymańska J., Kontrole na granicach wewnętrznych strefy Schengen: wyjątki staja się reguta, Biuletyn PISM Nr 17 (1590), 2018.

- „Menschlichkeit siegt. “ - Mit unserem Wahlprogramm!, https://www.spoe.at/wpcontent/uploads/sites/739/2019/09/Wahlprogramm-im-\%C3\%9Cberblick.pdf [access: 21.09.2019].

Summary: Nowadays, Austria is facing significant challenges in implementing integrational policy towards immigrants It's basic assumption is to enethe economic inclusion as soon as possible. On the other hand, the integration program generates quite high costs, and this fact is repeatedly used in public discussion. The emerging soccismscepticism towards immigration has become one of the reasons for the electoral success of the far right, which is considered to be the anti-immigrant Freedom Party of Austria. The article undertakes an analysis of a selected topic, including several aspects: the attitude of political parties towards the so-called immigration issues, the nature of 
election campaigns and government initiatives on Austria's immigration policy. On the other hand, the questions raised in the paper concern the following issunce whenidis the change in the nature of public discussion in Austria come about, under what influence have the factors of antiimmigrant rhetoric intensified and what are the effects of such rhetoric? Another important issue is whether nly Freedom Party of Austria remains the only carrier of such rhetoric.

Keywords: Austria, immigration policy, migration crisis, Freedom Party of Austria

\section{Antyimigrancka retoryka jako element życia publicznego w Austrii - wybrane aspekty}

Streszczenie: Współcześnie w Austrii realizowana jest polityka integracyjna. Podstawowym jej założeniem jest jak najszybsza ekonomiczna inkluzja imigrantów. Program integracji cudzoziemców generuje dość duże koszty, a fakt ten coraz częściej wykorzystywany jest w publicznej dyskusji. Pojawiający się sceptycyzm społeczny wobec imigracji stał się jedną z przyczyn sukcesów wyborczych skrajnie prawicowej, uchodzącej za antyimigrancką Wolnościowej Partii Austrii. W artykule podjęto analizę wybranego tematu z uwzględnieniem kilku aspektów: stosunku partii politycznych wobec tzw. kwestii imigranckiej, charakteru kampanii wyborczych oraz inicjatyw rządowych dotyczących polityki imigracyjnej Austrii. Postawione pytania dotyczą natomiast następujących kwestii: od kiedy mamy do czynienia ze zmianą charakteru publicznej dyskusji w Austrii, pod wpływem jakich czynników antyimigrancka retoryka uległa intensyfikacji oraz jakie są skutki takiej retoryki? Istotną pozostaje również kwestia czy nośnikiem takiej retoryki pozostaje wyłącznie Wolnościowa Partia Austrii.

Słowa kluczowe: Austria, polityka imigracyjna, kryzys migracyjny, Wolnościowa Partia Austrii 